\title{
Correction to: The ICU Liberation Bundle and Strategies for Implementation in Pediatrics
}

\section{Alice Walz ${ }^{1} \cdot$ Marguerite Orsi Canter $^{2} \cdot$ Kristina Betters $^{3}$}

Published online: 23 June 2020

(C) Springer Science+Business Media, LLC, part of Springer Nature 2020

\section{Correction to: Current Pediatrics Reports https://doi.org/10.1007/s40124-020-00216-7}

Table 2 of the original version of this article unfortunately was not formatted well, making it unclear for readers.

The original version has been corrected.

Publisher's Note Springer Nature remains neutral with regard to jurisdictional claims in published maps and institutional affiliations.

The online version of the original article can be found at https://doi.org/ 10.1007/s40124-020-00216-7

Kristina Betters

kristina.betters@vumc.org

1 Department of Pediatrics, Medical University of South Carolina, Charleston, SC, USA

2 Department of Pediatrics, NYU Winthrop Hospital, Long Island School of Medicine, Mineola, NY, USA

3 Department of Pediatrics, Vanderbilt University School of Medicine, Doctors Office Tower 5114, 2200 Children's Way,

Nashville, TN 37232, USA 